\title{
New Frontiers in Sovereign Wealth Fund Capitalization
}

\author{
Juergen Braunstein and Asim Ali
}

\section{Introduction}

This contribution takes its place alongside a small but growing literature that identifies new funding streams for the creation of SWFs (e.g. see, Schena et al. 2018; Gamlen et al. 2016; Braunstein and Caoili 2016; Braunstein et al. 2016; Atkinson and Hamilton 2016). While in the past it was primarily commodity wealth or current account surpluses that funded the creation of SWFs, policy makers are increasingly looking at non-traditional sources, such as taxes, immigrant investor programs and intellectual property rents (see Clarke 2016). Reflecting this change in potential funding sources, the actors involved in the debate are becoming more diverse. While in the past it was primarily the Ministry of Finance or Central Bank that was involved in the debate, other government departments and ministries, such as innovation departments, migration ministries, state-owned enterprise (SOE) ministries, and economic and development ministries, are increasingly getting involved. The objective of this chapter is to systematize existing research and identify promising but overlooked funding sources for future SWFs.

SWFs are large state investment funds that have become important actors in the international finance arena. SWFs have traditionally been established to recycle oil/gas, budget current account surpluses, and address a number of macroeconomic issues; for example, smoothing fiscal revenues, mitigating the Dutch disease or saving for future generations, protecting against capital supply shocks, stabilizing budgets, saving for future generations, and developing financial markets (Braunstein 2018). Mirroring these objectives, SWFs have tended to invest primarily into foreign

J. Braunstein (ه)

Harvard Kennedy School's Belfer Center, Cambridge, MA, USA

e-mail: juergen_braunstein@hks.harvard.edu

A. Ali $(\bowtie)$

The Fletcher Network for Sovereign Wealth and Global Capital, The Fletcher School of Law and Diplomacy, Tufts University, Medford, MA, USA 
assets. Following years of exponential growth, the number and size of new SWFs are uncertain, mainly because the key traditional drivers of SWF growth-notably oil price and current account surpluses-have slowed down.

SWFs are emerging in an international environment, and changes in this environment are reflected in the seemingly changing form and function of various SWFs (Clark and Monk 2010). The first generation of SWFs was strongly related to petrodollar flows, with the recycling of oil surpluses into the international financial system and intermediation thereafter of these financial flows via western financial institutions. The emergence of the SWF-mirrored international environment of liberalization of capital accounts and trade and industrialization provided further windfalls from the oil boom. The second generation of SWFs was strongly associated with emerging economies such as BRICS when countries with large trade surpluses started translating sizeable foreign reserves by investing in international equities and alternative financial instruments for attractive financial returns on their investments. The third generation of SWFs, this contribution suggests, are no longer being funded by the proceeds of hydrocarbon exports or export surpluses. Instead, with a focus on socio-economic and development objectives-when economic nationalism is surging and migration, trade, and foreign investment are increasingly becoming contested political issues-developing countries are finding innovative and alternative ways to mobilize foreign capital/aid flows and international financial markets. For example, while Turkey is following the footsteps of earlier examples such as Temask (Singapore) and Kazannah (Malaysia) but with new elements (raising significant amounts of capital on the international market), Bangladesh is trying something quite new, namely, the use of remittances. The possibility of using remittances as a source of funding would bring a number of hitherto non-mentioned countries, such as Armenia, into the SWF debate. However, a more nuanced picture has to be drawn in this emerging category of SWFs to account for varying political, economic, and institutional constraints. The paper is structured as follows: it provides a brief empirical overview on SWFs that were created with non-traditional sources of funding. Then it looks at remittances as a potential funding and revenue stream for creating new SWFs. Thereby it looks at Bangladesh, which discussed in early 2017 the creation of a remittance-funded SWF, and contrasts it with Armenia - a country which is even more dependent on remittance flows. It reveals important nuances that have to be taken into account when creating such a fund. Finally it looks at Turkey's and Indonesia's announced SWFs, which follow the footsteps of a number of well-established older SWFs but have interesting new elements.

\section{Overview}

A recent and increasingly prominent phenomenon in the SWF world relates to the creation of SWFs with development and strategic investment mandates that are designed to leverage and channel foreign direct investments into the domestic 
Table 1 Sovereign development funds

\begin{tabular}{l|l|l|l}
\hline Date est. & SWF name & Country & AUM in bn US\$ \\
\hline 1974 & Temasek & Singapore & 180 \\
\hline 1984 & IPIC & UAE & 58 \\
\hline 1993 & Khazanah Nasional & Malaysia & 34.9 \\
\hline 2002 & Mubadala & UAE & 63.43 \\
\hline 2006 & Invest. Corp of Dubai & UAE & 196 \\
\cline { 2 - 4 } & Mumtalakat & Bahrain & 11.1 \\
\cline { 2 - 4 } & State Capital Investment Corporation & Vietnam & 1.4 \\
\hline 2007 & CIC & China & 813.76 \\
\hline 2017 & Samruk Kazyna & Kahzakhstan & 49.9 \\
\hline
\end{tabular}

Source: Sovereign Wealth Center (2017)

economy (Schena and Ali 2016; see Table 1). Some of the most recent examples include the Fondo Strategico Italiano, the Russian Direct Investment Fund, and the Ireland Strategic Investment Fund but the idea of creating such funds is also increasingly gaining momentum in low and lower middle-income countries. Private equity capital seems particularly attractive for countries with underdeveloped public equity markets and shallow debt markets. Sovereign private equity seed funds serve as state-sponsored private equity entities (e.g. Senegal's FONSIS). In 2011 Morocco created Ithmar Capital as a strategic investment fund with the purpose of mobilizing national and international investment into the tourism sector. Financed by the government, Ithmar Captial co-invests in Moroccan projects with other SWFs, and partners with international financial institutions such as the World Bank (Schena and Ali 2016).

Countries with no macroeconomic justifications, such as Senegal or Italy, have already created SWFs. Others, such as Lebanon and Indonesia, are planning to create SWFs. Some of these countries have used government seed funding in the form of capital injections from other government departments or loans to create SWFs (e.g. Senegal, Italy, Panama, France). Others have used asset transfers, such as state enterprise reconfigurations, and merging of existing state investment firms/ funds (e.g. Singapore, Vietnam, Bahrain, Palestine). A number of countries, such as Panama and Luxembourg, have introduced or increased taxes, which then served as a revenue stream for their SWFs. Some countries that could not use the tax instruments for mobilizing funds leveraged their diaspora population for funding, which could then be channeled into a sovereign development fund (e.g., Rwanda). Interestingly, a few economies borrowed funds from the international capital market and re-channeled it into SWFs, which in turn invest in domestic projects (e.g. Ras-al Khaimah, UAE) (Reuters 2017). A thus-far unexplored territory is the study of remittances in the creation of SWFs as a possible funding channel to meet development finance objectives. 


\section{New Sources of Funding and Revenue Streams}

The absence of commodity wealth or current account surpluses is driving many governments away from traditional paths of SWF creation and towards new ways. Such new ways (see Table 2) include leveraging immigrant investor programs,

Table 2 Potential funding and revenue streams

\begin{tabular}{|c|c|c|c|c|}
\hline $\begin{array}{l}\text { New funding and } \\
\text { revenue streams }\end{array}$ & Drivers & Countries & SWFs & $\begin{array}{l}\text { AUM in } \\
\text { bn US\$ }\end{array}$ \\
\hline \multirow[t]{2}{*}{$\begin{array}{l}\text { Intellectual } \\
\text { property rents }\end{array}$} & $\begin{array}{l}\text { Technology, } \\
\text { innovation }\end{array}$ & Japan & IP bridge & $0.1-0.5$ \\
\hline & & France & Brevets & $0.1-0.5$ \\
\hline \multirow[t]{2}{*}{$\begin{array}{l}\text { Government seed } \\
\text { funding }\end{array}$} & $\begin{array}{l}\text { Intergovernmental } \\
\text { transfers }\end{array}$ & Senegal & FONSIS & 1 \\
\hline & & Panama & Fondoahorropanama & 1.39 \\
\hline $\begin{array}{l}\text { Government } \\
\text { borrows on the inter- } \\
\text { national } \\
\text { capital market }\end{array}$ & Low interest rates & UAE & $\begin{array}{l}\text { Ras-al Khaimah } \\
\text { Investment } \\
\text { Authority }\end{array}$ & 1.2 \\
\hline $\begin{array}{l}\text { State asset transfer/ } \\
\text { restructuration }\end{array}$ & & Turkey & $\begin{array}{l}\text { Turkish Wealth } \\
\text { Fund }\end{array}$ & $200^{\mathrm{b}}$ \\
\hline Diaspora funds & Donations & Rwanda & $\begin{array}{l}\text { Agarico } \\
\text { Development Fund }\end{array}$ & 0.039 \\
\hline Remittances & $\begin{array}{l}\text { Migration with } \\
\text { strong linkages to } \\
\text { home countries }\end{array}$ & Bangladesh & Bangladesh SWF & 10 \\
\hline \multirow[t]{2}{*}{$\begin{array}{l}\text { Exchange of } \\
\text { citizenship }\end{array}$} & Migration & Malta & $\begin{array}{l}\text { National } \\
\text { Development and } \\
\text { Social Fund }\end{array}$ & n.a. \\
\hline & & Canada & $\begin{array}{l}\text { Immigrant } \\
\text { Investment Fund }\end{array}$ & n.a. \\
\hline \multirow[t]{2}{*}{ Rare earths } & $\begin{array}{l}\text { Technology, } \\
\text { innovation }^{\mathrm{a}}\end{array}$ & China & n.a. & n.a. \\
\hline & & Russia & n.a. & n.a. \\
\hline Shale gas & Policy and oil price & UK & n.a. & n.a. \\
\hline Commodity tax (coal) & $\begin{array}{l}\text { Policy, } \\
\text { environment }\end{array}$ & India & $\begin{array}{l}\text { National Clean } \\
\text { Environment Fund }\end{array}$ & n.a. \\
\hline \multirow[t]{2}{*}{ Tax revenues } & Electronic VAT & Luxembourg & $\begin{array}{l}\text { Fonds souverain } \\
\text { intergénérationnel } \\
\text { du Luxembourg }\end{array}$ & $1^{\mathrm{b}}$ \\
\hline & $\begin{array}{l}\text { Toll fee (Panama } \\
\text { canal) }\end{array}$ & Panama & Fondoahorropanama & 1.39 \\
\hline
\end{tabular}

Sources: Clarke (2016); Gamlen et al. (2016); Braunstein and Caoili (2016); Braunstein et al. (2016); Atkinson and Hamilton (2016); ClimateChangeNews (2016); Agarico (2018); FONSIS (homepage); Fondoahorropanama (homepage); The Financial Times (07.02.2017); Bloomberg (02.08.2016; 07.02.2017); Ho and Y-Sing (2015); SWFInstitute (2017); Sovereign Wealth Center (2017)

${ }^{a}$ E.g. energy storage technology and high-tech equipment require rare earths

${ }^{\mathrm{b}}$ Projected 
borrowing from international finance institutions, and using the proceeds from special taxes/levies. With regard to the latter, Luxembourg aims to gather at least EUR 50mn per year from e-commerce VAT and a residual part from excise duties, and to reach EUR 1bn over a 20-year period for the 2015-created "wealth fund for intergenerational generations" (Braunstein et al. 2016). This fund was created in order to cover a part of future pension liabilities.

In a similar fashion, the Indian government created the National Clean Environment Fund with revenues from an increase in the coal tax (Climate Change News 2016). In order to increase confidence in the non-fossil fuel sector, the Modi government doubled the carbon tax on coal. The revenue flows into the National Clean Environment Fund, which then invests in clean energy projects (Climate Change News 2016). A consortium consisting of Turkey, Indonesia, and Saudi Arabia, backed by the Jeddah-based Islamic Development Bank, plans to raise financing and underwriting loans for the creation of the Islamic Infrastructure Investment Bank (Vizcaino 2015). In discussing the importance of intellectual property for national development, Clarke (2016) explores the creation of Sovereign Patent Funds (SPFs), which are new applications of SWFs in the global patent market. Once these SPFs are established, governments can support and protect their national champions in terms of litigation and gain additional revenue streams from patent rights. These so-called intellectual rents then become more important in smart societies. Thus far such funds have been mainly created in highly industrialized countries, such as Japan and France, with seed funding from other national finance vehicles (e.g. France's Sovereign Patent Fund was funded by the Caisse de Depot) (Clarke 2016). Similarly, the idea has arisen of leveraging immigrant investor programs (IIPs) - programs that involve the sale of national membership privileges to wealthy foreigners - and using finance capital that was exchanged for residency or citizenship rights to create immigrant investment funds. Structured like SWFs, such funds might be useful tools to invest in critical refugee and migrant infrastructure (Gamlen et al. 2016). An interesting but little-noticed move by a low-income country was made by Rwanda in 2012 when the president launched the Agaciro Development Fund (Agarico 2018). Its funding source also included voluntary donations from Rwanda's diaspora.

Other sources of SWF funding relate to large state enterprises and commodities, such as rare earth or shale gas. Inspired by the well-established oil-funded Norwegian SWF, Atkinson and Hamilton (2016) proposed the creation of a UK SWF, which could be funded by the proceeds from the export of shale gas. According to Atkinson and Hamilton (2016), the UK could have accumulated about GBP 280 billion by 2010 if they had created such a commodity fund in 1975 when they discovered oil in the North Sea. Likewise, the idea of using SWFs as vehicles to transform large SOE sectors is not novel (Kumar 1992). It reaches back to the 1970s when Singapore's government aimed to decrease the SOEs' dependence on the government budget. Singapore's government transferred the stakes of the Ministry of Finance Incorporation into Temasek-Singapore's SWF created in 1974 (Braunstein 2017). It created Temasek as a state-holding company. Whilst improving the fiscal situation, this was also intended to increase efficiency and 
eliminate redundancies through better coordination among SOEs. It could then even raise money on behalf of its companies via the market via issuance of bonds.

The idea of transforming SOEs into large state finance holding companies/SWFs experienced a revival in 2016, when Indonesia's government announced the creation of a US\$320bn SWF which will replace Indonesia's SOE Ministry.

Out of these 13 potential sources, two sources attracted significant attention in 2016 and 2017: SWF capitalization via remittances and SWF creation via stateowned enterprise restructuration. In order to get some more detailed information, the following part explores SWF capitalization via remittances in the pilot cases of Bangladesh and Armenia. Section 4 concludes with an overview of the most recent announcements of SOE restructuring and SWF creation in Turkey and Indonesia.

\section{Remittance Inflows: Challenges and Opportunities}

Migration and global diaspora resources are an integral part of the development process in many developing countries and an important lever of socio-economic development. Remittances refer to personal funding flows from expatriates to their friends and families back home. According to the World Bank Migration and Remittances Factbook 2016, global remittance flows are estimated to have exceeded US $\$ 601 \mathrm{bn}$, of which developing countries are estimated to receive over US\$441bn. Remittances have been a relatively stable source of external financing - more stable than foreign investment or development aid (Worldbank 2003). Around 247 million people, or $3.4 \%$ of the world population, according to the latest World Bank figures, live in a different country from that of their birth.

Interesting patterns of remittance growth can be observed across countries at different income levels. The rise in remittance flows reflects the steady increase in annual labor migration. While average remittance inflows in low-income countries remained low between 2000-2015, upper middle-income countries experienced on average a remittance inflow of US\$3bn in 2015, up from US\$500mn in 2000 (calculated with World Bank data 2016). Interestingly, the most dynamic growth in remittance inflows occurred in lower middle-income countries. On average, lower middle-income countries experienced a remittance inflow of more than US $\$ 5$ trn in 2015, up from approximately US\$700mn in 2000 (calculated with World Bank data 2016). Many of the lower-middle-income countries, such as Bangladesh, have experienced a dynamic growth in population. At the same time, most of these countries are lacking in social and economic infrastructure.

In many countries at different income levels, remittances constitute a critical part of their respective GDPs. Remittances are often critically important to bolstering foreign exchange reserves and meeting current spending needs. The rationale behind channeling a portion of remittance flows into a sovereign development fund is to insure more efficient management and investment in critical infrastructure (Schena 
and Ali 2016). A key objective or function of such a fund-e.g. FONSIS — would be to catalyze DFI by global investors so as to amplify the impact of local capital.

Remittances as sources of foreign exchange are particularly important for small open economies. For some low-income countries, for example, Nepal and the Comoros, remittances represent more than $25 \%$ of GDP (calculated with World Bank data 2016). For many developing countries, remittances constitute a large part of their FEX inflows and national income. In Tajikistan, for example, remittances represented around 50\% of the GDP in 2013 (calculated with World Bank data 2016). Interestingly, in upper middle-income countries, such as Lebanon, Albania and Bosnia, remittance flows have experienced a continuous decline between 2000 and 2015. In Bosnia and Herzegovina, for example, remittances represented around $10 \%$ of GDP in 2015, down from around 30\% in 2000 (calculated with World Bank data 2016).

Bangladesh and Armenia, too, rely on remittances as part of their budgetary needs but serve as examples of countries with similar remittance levels but with different implications for SWF creation.

\section{Bangladesh}

Bangladesh is a lower middle-income country. Given the myriad of economic challenges, Bangladesh will continue to record budget deficits between the fiscal years 2016/2017 and 2020/2021. The government is facing numerous challenges, ranging from the need to invest in power and water infrastructure to the necessity of raising spending on education and healthcare and reducing poverty to meet the targets of the Sustainable Development Goals (SDGs). The tax collection base remains low and thus the government will continue to struggle with funding, increasing fiscal deficits. For 2016/2017, according to Economic Intelligence Unit (EIU); the government forecasts that progress on widening the tax base will remain slow, weighing on revenue inflows and resulting in a budget deficit of $5.3 \%$ of GDP in that year. The fiscal shortfall will narrow to $4.6 \%$ of GDP by 2020/2021 as the tax base expands, although revenue as a proportion of GDP will average $10.6 \%$ in 2016/2017-2020/2021, one of the lowest levels in Asia (calculated with World Bank data 2016). However, there is hope, in addition to preferential market access to the EU and US markets, that a continuous growth in inflows of worker remittances will compensate for the persistent deficits in the trade, services and primary income accounts, enabling the current account to remain in surplus in 2017-2021.

SWFs were established with one or more objectives, whether to insulate the budget and the economy from excess volatility in revenues; help monetary authorities sterilize unwanted liquidity; build up savings for future generations; or for economic and social development. Bangladesh is one such example of a developing state that is considering deploying a fund for economic and domestic infrastructure development; herein are some ideas for other developing countries, with similar 
socio-economic profiles, that are trying to balance competing budgetary priorities. India, too, just launched an SWF- the National Investment and Infrastructure Fund (NIIF) - with the idea of a national development fund with a focus on natural resource/energy and infrastructural development sectors (Livemint 2016). In the Middle East, countries like Qatar and Kuwait, which suffer from arid land, for example, are strategically deploying their respective SWFs to acquire biotechnology and bio-agricultural technology from European states to manage water and food scarcities. Bahrain is using its fund to harness domestic human capital through a focus on engineering, education, and management sectors.

\section{Purpose of a Bangladeshi SWF: Remittances as a Funding Channel}

In 2015, Bangladesh's central bank chief, Atur Rahman, disclosed that the government is planning to establish an SWF through excess foreign exchange reserves to focus on national infrastructural development projects. In early 2017, the Bangladesh government announced the establishment of a possible \$10bn SWF that would be used for "any purposes in the public interest" (Asia Nikkei 2015). The fund is being floated via sequestering part of the FEX reserves, which had exceeded $\$ 30 \mathrm{bn}$ due primarily to the inflow of steady remittances (Xinhuanet 2017).

Bangladesh is correct to consider innovative options to meet its financial and development needs. With its steady flow of remittances, which in 2016 accounted for $65 \%$ of the country's foreign exchange reserve, Bangladesh is right to invest its reserves for long-term development objectives instead of borrowing or issuing sovereign bonds. According to the central bank of Bangladesh, the remittance inflow for the year 2014-2015 was US\$15.31bn, while the remittance inflow in 2013-2014 was US\$14.23bn-a steady jump from the approx. US\$7.9bn inflow in 2007-2008 (calculated with World Bank data 2016). By contrast, FDI (net inflows) was US \$3.38bn and US\$2.5bn in 2014 and 2013, respectively, according to World Bank data (calculated with World Bank data 2016). The steadily increasing inflow of remittance has to do with the central bank's efforts to facilitate the inflows through formal banking channels. As the structure and mandate of the Bangladeshi SWF are formalized, the creation of an SWF based on excess reserves derived principally via remittance inflows would be a novel idea and one that offers some stylistic lessons for other developing countries. 


\section{Economic and Political Rationale for a Bangladeshi SWF}

A Bangladeshi sovereign development fund capitalized via remittances would be a preferable alternative to foreign aid dependency or favorable trade access to leading markets (subject to the vagaries of the host country's political economic compulsions). Assuming a clearly defined financial-legal and political-economic mandate undergirding such a development fund, a remittance-based SWF provides the necessary funding sources for infrastructural development in a developing country like Bangladesh.

In the case of Bangladesh, an impoverished country with a large migratory labour force working in the Gulf Cooperation Council countries and other parts of the world, remittances are the bread and butter of most Bangladeshi families back home. As indicated earlier, international remittances in Bangladesh in 2015 stood at around $\$ 15 \mathrm{bn}$, covering almost $65 \%$ of the country's foreign exchange reserve for this period (calculated with World Bank data 2016). However, the success of a remittance-based SWF will be contingent upon the government-as the central bank of Bangladesh has been debating - creating a fund that can be sequestered for the broader development of the economy.

Once a remittance-based SWF fund is established, Bangladesh could develop an institutional mechanism to smartly co-invest the proceeds from inflows in national development projects and become less exposed, over time, to the vagaries of international capital and financial markets. Bangladesh is ideally positioned to leverage its strong development cooperation with non-traditional donors such as China, India, Iran, Kuwait, Malaysia, Saudi Arabia, Turkey, and the UAEincidentally, all southern states with SWFs of their own-and deepen its SouthSouth financial-economic engagement. It will also help mitigate sovereign and exchange rate risk as Bangladesh would be channeling its remittance-based SWF into tangible and long-term projects that would yield meaningful socio-economic and financial returns.

\section{Armenia}

Remittances have been the single-most critical external source of capital in Armenia in relative GDP terms, even larger than Bangladesh. Between 2008 and 2015, remittance inflows into Armenia were considerably higher than FDI inflows. As of 2015, about US\$1.6bn in remittances (around 15\% of Armenia's GDP) were sent to Armenia from other countries (calculated with World Bank data 2016). As of 2015, remittances were about the size of Armenia's total export revenues, almost nine times as high as FDI inflows and more than twice as high as portfolio investment inflows. In 2014, remittances were even significantly higher than Armenia's total 
export revenues. With an emigrant remittance stock of 785,740 as of 2015, approximately one-third of Armenia's population works abroad (World Bank, database 2016). On an annual average, each of the emigrants sends about US $\$ 2000$ back to Armenia. This is a considerable amount given the average monthly income in Armenia of US\$350 average in 2015 (Armstat 2017).

Yet the structural features in Armenia show that it is not only the size of remittances that matter for the creation of an SWF but also economic factors. If some remittances are formally allocated to a separate legal structure and invested in long-term projects, they will not qualify as FEX reserves under the IMF's definition. Armenia is extremely exposed to the political and economic vagaries of a single economy-Russia. The generation of remittances is out of the hands of the country, making it particularly vulnerable to sudden stops or decreases in remittance flows. As of 2015, about $60 \%$ of remittance flows to Armenia came from Russia (calculated with World Bank data 2016) so any economic downturn in Russia translates into reduced remittance inflows or remittance supply shocks in Armenia, leading to a decline in FEX reserves. This would leave the central bank and the Armenian currency vulnerable and encourage raiding the fund to backfill reserves (e.g., similar to what happened in Azerbaijan). Hence, Armenia's economy is closely linked to the business cycles of the Russian economy, which is a major reason why remittancerelated reserves are kept in the central bank.

Another promising route for SWF creation among many countries relates to the restructuration process of state-owned enterprise sectors. Countries with large SOE sectors, in particular, which do not want to privatize their SOEs, might choose the SWF route. This follows earlier models of state-holding companies-where governments try to separate ownership and management functions in order to permit the companies greater operational freedom from the state - combined with modern elements of attracting foreign capital via the issuance of bonds or for co-investments (Kumar 1992, Wall Street Journal, 17.02.2017).

\section{Capitalizing a Fund Through Restructuring State-Owned Enterprises (SOEs): Cases of Indonesia and Turkey}

Indonesia's announcement that it was creating an SWF in May 2016 was followed in February 2017 by Turkey's statement that it was creating a Turkish Wealth Fund. Turkey and Indonesia are following in Singapore's footsteps. It was in the early 1970s when the government of Singapore made the first move by transferring the stakes of the Ministry of Finance Incorporation into Temasek Holding-Singapore's SWF created in 1974. Singapore's other ministries followed suit by transferring their assets into similar holdings, such as the Sheng-Li Holding (defense-related industries) and the Ministry of National Development Holding (housing development and land corporations). Then, in the early $1980 \mathrm{~s}$, most of the assets were merged into Temasek's portfolio (Braunstein 2017). 
Indonesia's new SWF will be modeled after Malaysia's Khazannah Nasional and will reportedly control US\$320bn worth of assets by 2019 (Bloomberg, 17 May 2016). To accelerate the process, the government plans to create four sector-specific sub-holdings, starting with the energy sector (Braunstein and Caoili 2016) The new SWF will replace Indonesia's SOE ministry and act as the parent for 199 of the largest SOEs. In a similar fashion, the Turkish government announced the transfer of government stakes in a number of high-profile companies, such as Turkish Airlines, a Turkish oil company, Halkbank, and Turk Telekom, into an SWF (The Financial Times, 07.02.2017). The size of a Turkish SWF could reach US\$200bn (Bloomberg, 07.02.2017).

The creation of the Turkish Wealth Fund and the announcement of an Indonesian SWF reflect the latest developments in the evolution of SWFs created with the proceeds of large-scale state-owned enterprise restructuration. The rationale behind divesting state assets and putting the proceeds into an SWF is driven-partly at least-by the consideration to leverage national assets to raise money on the international capital market. Unlike earlier SWFs, notably Temasek, which issue bonds to get a rating and increase transparency, Turkey aims to raise money via its SWF on the international market for a number of high-profile infrastructure projects (The Financial Times, 07.02.2017). In the case of Indonesia, the aim of restructuring the SOE sector via the creation of an SWF is to decrease the SOEs' dependence on the government budget. While improving the fiscal situation, this should also increase efficiency and eliminate redundancies through better coordination among SOEs (Braunstein and Caoili 2016). In an age of increasing budget deficits and the need to reform large SOE sectors, other potential candidates for SWFs might also follow suit, including Pakistan and Iran.

\section{Conclusion}

The recent proliferation of SWFs among countries with no macroeconomic justification should not be surprising given their pledge of supporting national development agendas.

SWFs increasingly serve as an important dimension of the domestic political imperatives and economic policy considerations (i.e., economic diversification, economic development, macroeconomic stability) in the sponsoring states. This is reflected in their mandates, which have grown beyond their initial functions of stabilizing budgets and saving for future generations-via international portfolio investments - to include objectives related to domestic development purposes. These funds are increasingly integrated into the overall economic development strategy of the countries and can help generate long-term economic value and sustainability.

This contribution highlights - through four representative examples (Bangladesh, Armenia, Indonesia, and Turkey) - the need for more in-depth research into new frontiers in sovereign wealth fund capitalization in order to understand novel forms 
of state-driven financial engineering. Academics and policy makers are confronted with a new set of questions: What do these innovations mean for long and wellestablished SWFs, as well as their underlying theories? Recent examples of SWF formation show that the creation of such new SWFs not only depends on the availability of budget-, commodity-, and FEX surpluses. New capitalization channels are identified for creating SWFs, allowing governments without surpluses to create SWFs in order to leverage international capital for domestic policy purposes. What is the role of emulation and policy learning in the adaptation of these new forms of investment institutions? Does financial engineering in the SWF area occur on a continuum from less disruptive to radical innovation of institutions? If yes, what are the implications and unintended consequences?

For practitioners and scholars, financial engineering in the SWF arena offers the opportunity to identify creative ways of leveraging national assets and linking them to domestic and regional development agendas. Given the myriad socio-economic challenges facing these developing countries (water, electricity, population bulge, dilapidated infrastructure), sequestering a portion of revenues-derived via remittances or FDIs or exports-in a financial vehicle that could be deployed strategically for national economic development projects should be a national priority. However, this would tie significant amounts of FEX into long-term projects, which could become a problem in countries that have high exposure to single markets that are highly volatile.

A combination of increasing budgetary constraints and increasing domestic demand for basic services/infrastructure put increasing pressure on governments with large SOE sectors towards financial innovation. Here, financial engineering is about finding organizational formats that allow the leverage of existing national assets for the purpose of financing public goods and basic infrastructure services. SWFs will play an increasingly prominent role and as such they are expected to continue growing. However, establishing a depoliticized institutional mechanism for the management of such a fund would be a monumental task - as seen when the rentier proclivities of the ruling elite drained Nigerian and Libyan funds-for developing countries like Bangladesh. Many other countries with such fundsfrom liberal democracies (Norway Oil Fund) to the Gulf States (Qatar, Kuwait, UAE) to Southeast Asian countries (Malaysia, South Korea, China) to countries in Africa (Ghana) - among others - offer some successful lessons in how to deploy a national wealth fund.

\section{References}

Agarico. (2018). Overview. Accessed January 1, 2018, from http://www.agaciro.rw/index.php? $\mathrm{id}=34$

Armstat. (2017). Armenia statistics [homepage]. Accessed May 2, 2017, from http://www.armstat. $\mathrm{am} / \mathrm{en} /$ ?nid=126\&id $=0800>1$ 
Asia Nikkei. (2015, August 3). Bangladesh to launch sovereign wealth fund. Accessed September 3, 2016, from http://asia.nikkei.com/Politics-Economy/Economy/Bangladesh-to-launch-sover eign-wealth-fund-central-bank-chief

Atkinson, G., \& Hamilton, K. (2016). Asset accounting, fiscal policy and the UK's oil and gas resources, past and future (Working paper no. 250). Grantham Research Institute on Climate Change and the Environment, pp. 1-27.

Braunstein, J. (2017). The domestic drivers of state finance institutions: Evidence from sovereign wealth funds. Review of International Political Economy, 24(6), 980-1003.

Braunstein, J. (2018). Domestic sources of twenty-first-century geopolitics: Domestic politics and sovereign wealth funds in GCC economies. New Political Economy, 1-21.

Braunstein, J., \& Caoili A. (2016). Indonesia: The vanguard of a new wave of sovereign wealth funds? LSE government blog. Accessed September 2, 2017, from http://blogs.lse.ac.uk/govern ment/2016/08/30/indonesia-the-vanguard-of-a-new-wave-of-sovereign-wealth-funds/

Braunstein, J., Laboure, M., \& Sen, J. (2016). Windfall revenues in Europe: What's next? LSE euro crisis in the press blog. Accessed May 2, 2017, from http://blogs.lse.ac.uk/eurocrisispress/2016/ 12/16/windfall-revenues-in-europe-whats-next/

Clark, G., \& Monk, A. (2010). Sovereign wealth funds: Form and function in the 21 st century (Working paper).

Clarke, W. (2016). Sovereign patent funds: Sovereign wealth funds 2.0? Global Policy, 7(4), 577-583.

Climate Change News. (2016). Will doubling indias coal tax boos the clean energy sector? Accessed April 1, 2016, from http://www.climatechangenews.com/2016/04/01/will-doublingindias-coal-tax-boost-the-clean-energy-sector/

Gamlen, A., Kutarna, C., \& Monk, A. H. B. (2016). Re-thinking immigrant investment funds (Working paper no. 128). Oxford: University of Oxford.

Ho, Y., \& Y-Sing, L. (2015). Indonesia seeks stature by hosting islamic development bank unit. Bloomberg. Accessed April 15, 2015, from https://www.bloomberg.com/news/articles/201504-15/indonesia-seeks-stature-by-hosting-islamic-development-bank-unit

Kumar, A. (1992). The state holding company: Issues and options (pp. 1-67). World Bank WDP187.

Livemint. (2016, July 15). India's sovereign wealth fund identifies first eight projects for investments. Accessed March 2, 2017, from http://www.livemint.com/Companies/ II3QqngchIvMdQ4skDqijN/Indias-sovereign-wealth-fund-identifies-first-eight-project.html

Reuters. (2017, February 9). Emirate of Ras Al Khaimah in talks with banks for dollar bond. Accessed February 10, 2017, from http://www.reuters.com/article/ras-al-khaimah-bondidUSL5N1FU3YI

Schena, P., \& Ali, A. (2016). Sovereign wealth fund investment in economic transformation: Toward an institutional framework (Working paper). Investment Funds for Development, Community of Practice World Bank.

Schena, P. J., Braunstein, J., \& Ali, A. (2018). The case for economic development through sovereign investment: A paradox of scarcity? Global Policy, 9(3), 365-376.

Sovereign Wealth Center. (2017). SWF rankings (homepage). Accessed December 15, 2017, from http://www.sovereignwealthcenter.com/

SWFInstitute. (2017). SWF ranking (homepage). Accessed September 1, 2017, from https://www. swfinstitute.org/

Vizcaino, B. (2015). Saudi Arabia to join Turkey, Indonesia in infrastructure Islamic Bank. Reuters. Accessed May 23, 2016, from http://www.reuters.com/article/us-islamic-financesaudi-idUSKCNOYE0U1

World Bank. (2003). Workers' remittances: An important and stable source of external development finance. Accessed May 2, 2016, from http://siteresources.worldbank.org/INTRGDF/ Resources/GDF2003-Chapter7.pdf 
Xinhuanet. (2017). Bangladesh cabinet approves proposal to set up sovereign wealth fund. Accessed February 6, 2016, from http://news.xinhuanet.com/english/2017-02/06/c _ 136035956.htm

Open Access This chapter is licensed under the terms of the Creative Commons Attribution 4.0 International License (http://creativecommons.org/licenses/by/4.0/), which permits use, sharing, adaptation, distribution and reproduction in any medium or format, as long as you give appropriate credit to the original author(s) and the source, provide a link to the Creative Commons licence and indicate if changes were made.

The images or other third party material in this chapter are included in the chapter's Creative Commons licence, unless indicated otherwise in a credit line to the material. If material is not included in the chapter's Creative Commons licence and your intended use is not permitted by statutory regulation or exceeds the permitted use, you will need to obtain permission directly from the copyright holder. 